\title{
Topical Issues of Criminal Liability of Medical or Pharmaceutical Workers under the Criminal Code of Ukraine (Article 140 of the Criminal Code of Ukraine)
}

\author{
Sofiia Lykhova, Iryna Ustynova, Olga Husar, Iryna Tolkachova.
}

\begin{abstract}
The issues of Improper protection of rights and legal interests of the patients due to improper performance of professional duties by a medical or pharmaceutical worker are considered. In particular, problems arising during the application of the norm of criminal liability for specified socially dangerous acts are considered. At the same time, cases of serious consequences to the patient's life and health due to a medical error or actions of medical or pharmaceutical workers committed in the absence of fault are considered although they result in the death of the patient or other grave consequences. Particular attention is paid to iatrogenic mental illness, caused by improper professional activity of the medical workers and peculiarities of the psyche of the patients. Particular attention is paid to the study of the practice of the European Court of Human Rights regarding the legal guarantee of the right to life in Ukraine in the context of criminal proceedings. Ukraine is a party to virtually all international human rights treaties. It imposes on it the obligation to adhere to European norms in the field of human protection. The need for comparative study of laws and effectiveness of their application at the present stage of society's development is due to the process of globalization affecting today not only economic and political processes but also the process of lawmaking. This requires the lawyers of different countries to join in the development of the theoretical foundations of lawmaking to formulate in the aggregate knowledge about the effect of laws based on world legal traditions and experience of the separate states. The complex structure of the health care organizations has led to the need for new models of healthcare professionals to ensure the quality of care and patient safety. In the current situation, patient safety is one of the new challenges faced by the medical students in undergraduate and postgraduate education. This involves incorporating a patient safety culture into curricula, in particular for the doctors and other health care professionals. The scientific article is aimed at solving the issues of criminal law protection as the rights of people in need of the medical services as well as medical and pharmaceutical workers who provide these services.
\end{abstract}

Keywords: medicine, pharmaceutical worker, patient, disease, medical error, service, aid.

Revised Manuscript Received on November 15, 2019

* Correspondence Author

Sofiia Lykhova, National Aviation University (Kyiv, Ukraine), https://orcid.org/0000-0001-7143-5325,k_kpipp@ukr.net,

+38(067)-446-94-85,

Iryna Ustynova, National Aviation University (Kyiv, Ukraine),

Olga Husar, National Aviation University (Kyiv, Ukraine),

Iryna Tolkachova, National Aviation University (Kyiv, Ukraine)

\section{INTRODUCTION}

The development of the legal state implies the need to protect universal values. Throughout the civilized world, it is recognized that a human, its life and health, inviolability and security are the highest social priorities that are to be protected by all branches of law. The most socially dangerous encroachments on these objects are protected by the norms of criminal law. Providing a human with qualitative and qualified medical care is one of the obligatory conditions for realization of the right to life and health of a human.

In particular, Ukraine has developed a complex legal mechanism that covers a wide range of standards that provide citizens with a guarantee of an efficient and affordable system of health care. One of the links of this mechanism is the criminal law providing for the responsibility of doctors and pharmaceutical workers for such crimes as "Failure to assist the sick medical officer" (Article 139 of the Criminal Code of Ukraine), "Violation of the patient's rights" (Article 141 of the Criminal Code of Ukraine), "Improper performance of professional duties having caused the person to be infected by a human immunodeficiency virus or other incurable illness" (Article 131 of the Criminal Code of Ukraine), "Disclosure of information about medical examination for the detection of human immunodeficiency virus infection or other incurable infectious diseases" (art. 132 Criminal Code of Ukraine)," Improper performance of professional duties by medical or pharmaceutical workers "(Art. 140 of the Criminal Code of Ukraine).

Special attention is paid by the researchers in the field of criminal law to the investigation of liability for failure to perform or improper performance of professional duties by a medical or pharmaceutical worker. According to calculations, at least 1,500 Ukrainians every year are the victims to this socially dangerous act. The widespread dissemination of this crime is evidenced by numerous media reports.

The peculiarity of this crime is its high latency. At the researchers' opinion the reasons for this latency are: lack of effective procedures for monitoring and review complaints; judicial practice, testifying to the practical inability to prove the fact of medical error or negligence; legislative gaps regarding the requirements for the executing and keeping of the medical documents. In addition, those who carry out medical examinations are a part of a medical structure that often cares about the rights of the patients but about the "honor of the uniform" [1]. It all undermines the authority of medicine and law enforcement

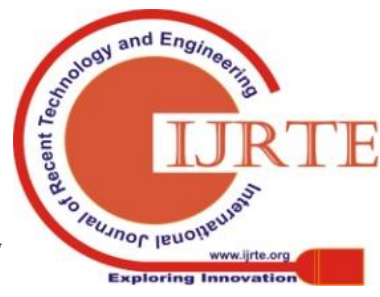


agencies, promotes the criminalization of the entire sphere of the medical and pharmaceutical services.

In the Criminal Code of Ukraine in 2001 in the Art. 140 the lawmakers for the first time have foreseen the liability of a medical and pharmaceutical worker for failure to perform or improepr fulfillment of their professional duties. At the same time, it should be noted that there were problems in determining the features of this crime, its separation from other crimes in the medical sphere. A separate problem arises from the definition of the concept of "medical error" and its relationship with the failure or improper fulfillment of professional duties by a medical or pharmaceutical worker.The problem is also debatable when the medical or pharmaceutical worker performs its professional duties, that is, causing socially dangerous consequences as a result of the professional activity of the said persons in the absence of guilt in the form of intent or negligence.

GOALS OF THE ARTICLE is to study the problems that arise in the application of the criminal law, provided in the Art. 140 of the Criminal Code of Ukraine and making suggestions on improvement of certain elements of the legal composition of the crime "Failure to fulfill or improper fulfillment of professional duties by a medical or pharmaceutical worker".

\section{MATERIALS AND METHODS}

The methodological basis of this research is made up of the methods that all together allow us to investigate scientific advances in this field and to come up with scientifically substantiated proposals to increase the standard of criminal liability of medical and pharmaceutical workers. The formal and dogmatic method allows for a legal interpretation of criminal-law norms and individual terms. Using the method of systematic and structural analysis, the signs of failure or improper fulfillment of professional duties by a medical or pharmaceutical worker were investigated. Comparative legal method is used in the analysis of criminal law of certain foreign countries. In addition, common cognitive methods such as the method of deduction, logical and semantic method and the method of systematization are used. The basis of this research is the work of well-known scientists not only in the field of law but also in the field of medicine, biology, bioethics because the problem of responsibility of medical or pharmaceutical workers has complex inter-sectoral nature.

\section{RESULTS}

Analysis of criminal liability of medical or pharmaceutical workers can reveal those issues that need improvement at the normative level. Correct and unambiguous understanding of the content of certain features of the legal composition of the crime contributes to the correct classification of this socially dangerous act, which, in turn, will reduce the level of its latency.

It will also, firstly, optimize the provision of quality and safe medical services to the Ukrainian citizens, and secondly, increase the level of responsibility of medical and pharmaceutical workers for their professional activities.

\section{DISCUSSION}

within Ukraine's integration into the world-wide community, the study of foreign law and legal experience of foreign countries becomes important scientific theoretical and practical significance. Comparison of the legal systems of different states provides an additional opportunity to better understand the domestic criminal law. It is necessary and expedient to use the experience of foreign countries in the process of further improvement of the criminal legislation of Ukraine. The legal literature emphasizes the importance of studying the provisions of a special part of the criminal law of foreign countries in view of the following factors: the expansion of international relations, leading to an increase in the number of Ukrainian citizens who are in the jurisdiction of foreign states and the foreigners who stay in Ukraine; internationalization of crime; active participation of Ukraine in the European Council and the council of other international organizations; improvement of domestic legislation by studying foreign experience.

Special attention should be paid to the practice of the European Court of Human Rights regarding the legal guarantee of the right to life in Ukraine in the context of criminal proceedings [2]. Ukraine is a party to virtually all international human rights treaties. It imposes on our country the obligation to adhere to European norms in the field of human protection. The need for comparative study of laws and the effectiveness of their application at the present stage of society's development is due to the process of globalization, affecting today not only economic and political processes but also the process of lawmaking. This requires the lawyers of different countries to join in the development of the theoretical foundations of lawmaking which ultimately should take shape in the aggregate of knowledge about the effect of laws based on world legal traditions and experience of separate states [3].

Criminal liability of a medical or pharmaceutical worker for failure to fulfill or improper fulfillment of professional duties under the criminal law of the European countries. To study foreign experience, the relevant rules contained in the Criminal Code of Austria [4], the Criminal Code of the Netherlands (official name of the state - the Kingdom of the Netherlands) [5], the Criminal Code of Denmark (official name of the state - the Kingdom of Denmark) [6], the Criminal Code of Spain (official the name of the state is the Kingdom of Spain) [7], the Criminal Code of the Republic of Bulgaria [8], the Criminal Code of the Republic of Poland [9], the Criminal Code of Norway [10], the Criminal Code of France (official name of the state - the French Republic) [11], the Criminal Code of the Federal Republic of Germany [12] CK of Switzerland (official name of the state - Swiss Confederation) [13], Criminal Code of Sweden (official name of the state - Kingdom of Sweden tion) [14] were analyzed.

A characteristic feature of most of the criminal codes analyzed is that they do not impose the responsibility for failure or improper fulfillment of their professional duties by a medical or pharmaceutical worker in an independent article (part of the article), however, criminalized careless professional conduct that causes harm to life and health of the person. At the same time criminal liability can come under the following articles of the codes of these states:

- death due to negligence, inexperience in the field or profession (Article 123 of Section I "Murder", chapter II "Offenses against a human" of the Criminal Code of the Republic of Bulgaria);

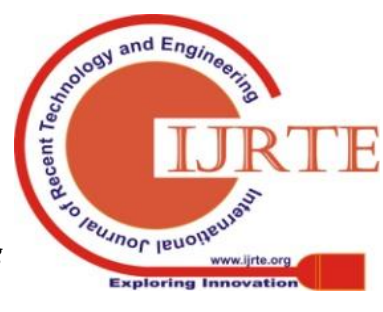


- death or serious bodily harm due to negligence of the responsible person (Articles 307-308 of the part XXI "Death and injuries due to negligence" of the CC of the Netherlands);

- murder due to negligence, connected with professional activity of the perpetrator (part 3 of the Article 142 of section I of the book II "Crimes and punishment" of the Criminal Code of Spain);

- death to another person as a result of error, negligence or failure to perform the safety or warning duties prescribed by law or regulations (Article 221-6, Section II, Section II, Chapter II, "On the assault on a person's life", Criminal Code of France).

In the codes analyzed, the article that criminalizes the careless professional conduct causing damage to a human's life and health is placed in the sections against life and health to be considered crimes against a human (section I, chapter II of the Criminal Code of the Republic of Bulgaria, Section XI of the Criminal Code of the Netherlands, chapter 25 of the Criminal Code of Denmark, division II of Chapter II of Chapter I of the Criminal Code of France), as a crime against life and health (paragraph 88 of the section I of the special part of the Criminal Code of Austria, section XIX Criminal Code of the Republic of Poland, section I of the second book of the Criminal Code Switzerland, the third chapter of the Criminal Code of Sweden), as a crime against life, body and health (paragraph 229, chapter 22 of the Criminal Code of Norway).

The analysis of the criminal codes of certain European states has clearly demonstrated that the legislator of these countries does not specify the characteristics of the victim.

All components of the crimes in the codes aalyzed have material composition and are considered to be complete since the day of committing a socially dangerous act which recognizes the grave or moderate gravity of bodily harm (Part 1 of the Article 134 of the Criminal Code of the Republic of Bulgaria), causing death or injury (Article 307-308 of the section XXI of the Criminal Code of the Netherlands, Article 221-6 of division II of section II of chapter I of the Criminal Code of France, section XVII of paragraph 229 of the Criminal Code of Germany, Article 8 of the Criminal Code of Sweden, Article 125, Section II of the Second book of the Criminal Code of Switzerland, Article 156 of the Criminal Code of Poland); death (Part 1 of Article 123 of the Criminal Code of the Republic of Bulgaria, paragraph 241 of the Criminal Code of Denmark, Article 117 and section of the Second book of the Criminal Code of Switzerland, Article 8 of the Criminal Code of Sweden, section XVI of paragraph 222 of the Criminal Code, article 155 of the Criminal Code of Poland), death to more than one person (Clause 3 of Article 123 of the Criminal Code of the Republic of Bulgaria).

The subject of the most relevant crimes in the criminal codes of the separate European states is special and is defined as the person engaged in the relevant activity. The subjective part of the syllables of crime, as foreseen in the disposition of the analyzed articles of the criminal codes, is not specified, however, its content follows from the nature of the act itself and consists in the careless attitude of the subject of the crime to the commission of a socially unscrupulous act.

The penal codes of the analyzed European states for non-fulfillment or inappropriate fulfillment of the medical or pharmaceutical worker's professional duties include variety of punishments: a fine (paragraph 214 of the Criminal Code of Denmark, Section XVII, paragraph 229 of the Criminal Code of Germany, Article 117 of the Criminal Code of Switzerland, Article 8 of the Criminal Code of Sweden; Article 308 of the Criminal Code of the Netherlands, Article 221-6 of the Criminal Code of France, Article 196 of the Criminal Code of Spain), simple imprisonment (paragraph 241 of the Criminal Code of Denmark), imprisonment (Part 3 of Article 142 of the Criminal Code of Spain, Article 308 of the Criminal Code of the Netherlands, Article 221-6 of the Criminal Code of France, Article 155 of the Criminal Code of the Republic of Poland, paragraph 249 of the Criminal Code of Denmark, Articles 7-8 of the Criminal Code Sweden, Section XVI, Section 222, Section XVII, Paragraph 229 of the Criminal Code of the Federal Republic of Germany, paragraph 229 of the Criminal Code of Norway).

Special attention is paid to the problem of studying the causes of death of the patients in healthcare facilities in the United States of America. The annual list of the most common causes of death in the United States, compiled by the Centers for Disease Control and Prevention (CDC), annually informs the public and the national scientific community. The list is created using the death certificate, filled in by doctors, funeral directors, medical experts and coroners. However, the main limitation of the death certificate is that it relies on the assignment of the International Classification of Diseases (ICD) code of causes of death and individual factors may not be taken into account. The science of safety is ready to describe how gaps in communication, diagnostic errors, unprofessional judgments and inadequate skills can directly lead to illness and death of the patient. We analyzed the science fiction literature to determine its contribution to US mortality for the causes listed by the CDC [15].

Also, the safety of patients is widely discussed in the scientific circles of Turkey. Background Patient safety and medical errors are among the most discussed topics in recent years. Identifying and reporting medical errors is one of the most significant steps toward the adoption of measures to increase patient safety. Objectives The goal of this descriptive, cross-sectional study was to evaluate attitudes toward patient safety and the tendencies to medical error among cardiology and cardiovascular surgery nurses in Turkey. Methods The study sample consisted of nurses who worked in the cardiology and cardiovascular surgery departments of a University Hospital in Izmir, the third largest city in Turkey. A total of 103 nurses working in the day shift of the mentioned departments volunteered and participated in the study. A "Nurse Information Form," a "Patient Safety Attitude Questionnaire (PSAQ)," and a "Malpractice Tendency Scale in Nursing-(MTSN)" were used as data collection instruments. Results The mean \pm 1 standard deviation of the nurses' PSAQ scores were 141.86 \pm 18.39 , whereas their MTSN scores were $237.20 \pm 18.12$. Although no statistically significant difference could be evidenced between cardiology and cardiovascular surgery nurses in their total MTSN scores $(\mathrm{t}=-0.99, \mathrm{P}=0.32)$, their PSAQ scores showed a significant difference $(\mathrm{t}=2.34, \mathrm{P}=0.02)$ [16].

Let us focus on certain issues arising in the criminal legislation of Ukraine regarding the application of the norm on criminal liability of medical or pharmaceutical workers and the solution of which will contribute to improving the legal protection of the rights and interests of the patients. In the disposition of the Art. 140 of the Criminal Code of Ukraine the

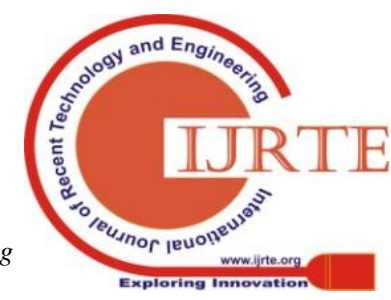



(Article 140 Of the Criminal Code of Ukraine)

victim is the patient whose health suffered grave consequences. In our opinion, such a wording should not be considered perfect. To apply for a health care service, a medical or pharmaceutical worker cannot only be sick, that is, the person who is ill, unhealthy but also the person who wants to undergo a medical examination, to determine its health condition, a woman who is pregnant without pathologies, person who volunteers to provide cosmetology services, etc. Therefore, in our opinion, the use in the disposition of the Part 1 of the Art. 140 of the Criminal Code of Ukraine the term "sick" greatly narrows the scope of the concept of the victim in this part of the crime. The use of the term "patient" will be more successful in designating the victim.

A separate problem arises in the analysis of such signs of the legal composition of the crime "Improper fulfillment of professional duties by a medical or pharmaceutical worker" as an act and consequences [17]. It is considered that under the grave consequences of this crime the human death, its suicide, the infliction of severe bodily harm and so on. If the result of failure or improper fulfillment of professional duties by a medical or pharmaceutical worker is deterioration in the social status of a human, then this structure of the crime is absent [18]. It is difficult to agree with and the issue of grave consequences should be solved simultaneously with the analysis of such a sign of the objective side of this form of crime as an act.

In our opinion, the serious consequences should include a specific mental illness, corresponding to the term "iatrogeniya". This is especially true for the geriatric patients [19]. A medical or pharmaceutical worker can commit the crime not only through action or inaction but also by the so-called "mixed inactivity". This form of act takes place when the subject of an offense carries out his professional duties in verbal form, verbally, but does it wrong, insufficiently correct or incomplete. These are actions that indicate the incompetence of a medical professional and do not meet the requirements of medical science. It has been found that iatrogenic mechanisms play role in shaping the false concept of the disease and destructive behavioral strategies leading to the chronization and progression of diabetes mellitus. The patients with diabetes who underwent long and ineffective numerous diagnostic procedures and ineffective treatment in the primary health care facilities, need psychiatric counseling and psychotherapeutic support [20].

Describing the inadequate fulfillment of professional duties by a medical or pharmaceutical worker in a verbal form is advisable to point out that depending on the type of nervous system, the peculiarities of the psyche, different patients react differently to certain words from medical or pharmaceutical workers. In particular, an ill-informed diagnosis or prolonged silence of a medical or pharmaceutical worker may cause a mental illness (iatrogeny) since the main and primary component of the negative effects of the word is the patient's emotional response. Mental trauma from an emotional reaction can cause a sense of despair, fear, experience for their fate, life and health. The consequence of this can be the suicide of the patient.

The word "iatrogeniya" means a mental illness (psychogeny), caused by careless word or act (behavior) of a medical worker.

We support the opinion of some scholars that it is impossible to provide health information to the patients with irreversible pathological changes in the body.
Particular attention should be paid to clarification of the content of such an optional feature in the legal composition of the crime, provided for in the disposition of the Art. 140 of the Criminal Code of Ukraine as a situation of committing a crime, namely, the time of fulfillment of professional duties. Effective communication between the attending and resident surgeon in the operating room is necessary to prevent surgical errors. However, existing studies do not describe how successful intraoperational training looks and how it prevents errors [21]. Medical or pharmaceutical workers perform their professional duties while providing medical care, medical services, medical practice. If the concept of "medical practice" has been defined in Ukrainian legislation, then the other two concepts - "medical care" and "medical service" do not have the definition in the legislation of Ukraine, making it difficult to establish correlation between them.

There is no definition of the concepts of "medical care" and "medical service" and in international acts. In particular, the Convention on minimum standards for social security (Geneva, June 28, 1952), the European Code of Social Security (Strasbourg, April 16, 1964) does not include the term "medical service" but it is noted that the term "medical care" covers prevention and treatment. The Amsterdam Declaration on Patient Rights in Europe, adopted by the European Conference on Patients' Rights on March 30, 1994, states that medical care is a medical service.

In accordance with the provisions of formal logic, the concept of "medical service" and "medical care" belong to the related concepts that are in the subordination relationship. At the same time, the concept of "medical care" is narrower and the broader is "medical service".

We consider it expedient in the disposition of the Part 1 of the Art. 140 of the Criminal Code of Ukraine specify the terminology of "professional duties" as an indication that they are carried out when providing specific medical care within the framework of provision of medical services. The medical service is provided in an out-patient, in-patient, in-patient emergency, in the manufacture of medical products, etc. Medical services should include not only specific medical care for the sick person but also professional responsibilities for the improvement, diagnosis, rehabilitation, prevention, cosmetic operations, artificial insemination, etc.

Within such a compulsory sign of the legal composition of the crime as the subject of the crime, it is necessary to pay attention to such an issue as the so-called special or professional sanity which determines the state of a person of a particular profession. It is necessary to raise the issue of special sanity with regard to medical or pharmaceutical workers since there are many examples where medical care is provided in extreme conditions and is associated with neuropsychic overloads to arise in case of making vital decisions in short period of time.

In order to find out whether criminal or medical professionals should be prosecuted in a state of professional (insensitive) insanity, it is necessary to determine how neuropsychic overload during the provision of health care affects their ability to realize their actions (inactivity) and/or manage them. The scientists-psychiatrists say that in some cases, the prolonged duration of occupational overload can cause a variety of psychogenic diseases - neurosis, psychosis or psychopathy which in general are characterized by excessive 
excitability, irritability, visual hallucinations, as well as psychopathic conditions, accompanied by a disorder of consciousness and therefore belongs to temporary disorders of mental activity which makes it possible to recognize such persons as insane.

Therefore, if a medical or pharmaceutical worker medical service and cannot realize his actions (inaction) or manage them, then there is every reason to admit him insolent. If nervous and psychological overload has caused confusion, fatigue, while maintaining the ability to realize their actions (inaction) and manage them, he or she is either prosecuted or liable to criminal liability (in the case of innocent harm). And therefore, we consider the position of he scientists regarding the impact of professional (special) insanity on the criminal liability of the individuals, including medical or pharmaceutical workers more reasonable.

\section{CONCLUSION}

Summing up the provisions set out in this research, it should be noted that the provision of high-quality, timely and affordable medical services is one of the main functions of the state in protecting the life and health of citizens of the country. In Ukraine there is legislation aimed at regulating healthcare relations. This legislation is characterized by multidirectional approach and includes the norms of many branches of law, both medical and civil and criminal.

Despite the expectation that doctors should have diagnostic and therapeutic reliability of $100 \%$, the truth is that the human condition is associated with an error in any activity, and the practical application of medicine is no exception because by its nature the medical science is somewhat imperfect, and the expectation of perfection is neither realistic nor possible. This does not mean that nothing can be done to reduce the frequency and reduce the number of negative consequences of medical errors. The complex tructure of healthcare organizations and healthcare processes has led to new models of healthcare professionals in order to guarantee the quality of care and safety of the patients. In the current situation, patient safety is one of the new challenges faced by the medical students in undergraduate and postgraduate education. This involves incorporating a patient safety culture into curricula, in particular for the physicians and other health professionals [22].

One of the guarantees of professional performance by medical or pharmaceutical workers is their criminal law, providing for punishment for failure to perform or improper fulfillment of the professional duties by medical or pharmaceutical workers. The reciprocity in this article, "as a result of a negligent or unscrupulous attitude towards them (duties)," unjustifiably suggests that medical staff carelessly violate their duties. Obviously, in some cases, such acts can be committed intentionally. One should also pay special attention to the fact that a socially dangerous consequence in the form of serious harm to the health of the patient, its death may be an accident, that is, the fault of a doctor or other health care worker may be absent from the grave consequences. This situation arises from the fact that there may be a situation that even the most experienced physician can inadvertently envisage, as well as conditions that exist objectively and inevitably result in a grave consequence even in the presence of highly professional medical workers. In such cases, experiences psychogenic illness during the provision of

criminal liability is excluded.To do this, it is necessary to investigate all problematic issues that arise in connection with the criminal-legal characterization of the legal composition of the crime provided for in the disposition of Art. 140 of the Criminal Code of Ukraine «Improper performance of professional duties by medical or pharmaceutical worker». This provides a real opportunity to protect both the rights of patients from socially dangerous acts of medical workers and to avoid criminal prosecution of these persons in the absence of a crime in their actions, that is, to protect the rights of health workers from unlawful prosecution in the commission of a crime.

\section{REFERENCES}

1. Tarasevych T.Yu. Medical worker as a special subject of the crime: thesis research ... PhD in Law: special 12.00.08 / Tarasevych Tetiana Yuriivna. - K., 2011

2. The right to life in the context of criminal proceedings: the practice of the European Court of Human Rights and the legislation of Ukraine. Kyiv, Right. 2019

3. Lykhovaya S.Ya. Criminological characteristic of violent crime: comparative legal analysis/ S.Ya. Lykkhovaya, A.N. Bilyakov, N.M Trush // Criminological magazine of the Baikal State University of Economics and Law. - 2013. - No. 1 (23). - P. 107-113.

4. Austrian Criminal Code. Federal law as of January 13, 1974. on criminal offenses (in the latest edition dated December 30 , 2014) / http://germanlaw24.com/index/ugolovnyj_kodeks_avstrii_na _russkom_jazyke/0-94.

5. Dutch Criminal Code: Published on March 5, 1881. The information was updated on January $18, \quad 2007$ / http://law.edu.ru/norm/norm.asp?normID=1242430\&subID=100100 457,100100458,100100510,100101139.

6. Danish Criminal Code: Adopted in 1930 Order No. 648 as of August 12, 1997, as amended by the Law No. 403 as of June 26, 1998, Law No. 473 as of July 1, 1998 and Law No. 141 as of March 17, 1999 Information updated: 10.01.2007 / http://law.edu.ru/norm/norm.asp?normID=1241524.

7. Criminal Code of Spain, 1995. Information updated: 07.03.2007/ http://www.law.edu.ru/norm/norm.asp?normID=1247923.

8. Criminal Code of Bulgaria (as last amended on April 26, 2011) / https://wipolex.wipo.int/ru/legislation/details/446.

9. Kodeks karny ze schematami. Przepisy dwujęzyczne. Teksty ustaw :Olga Sitarz, Wolters Kluwer 2018, str. 142.

10. Norwegian Criminal Code of 2005 / http://www.norge.ru/streffelov.

11. Criminal Code of France (as of 01.01.2014)/ https://wipolex.wipo.int/ru/legislation/details/14297.

12. Criminal Code of the Federal Republic of Germany: text and scientific and practical commentary. - M .: Prospect 2010. - 280 p.

13. The Swiss Criminal Code as of 21.12.1937 (as of 11.07.2017)/ https://wipolex.wipo.int/ru/legislation/details/17169.

14. Swiss Criminal Code http://www.sweden4rus.nu/rus/info/juridisk/ugolovnyj_kodeks_shvec ii

15. Makary M.A., Daniel M. Medical error-the third leading cause of death in the US / http://www.bmj.com/content/353/bmj.i2139.full.pdf. doi:10.1136/bmj.i2139.

16. Ozer S., Kankaya H.S., Toptas H.A., Aykar F.S. Attitudes Toward Patient Safety and Tendencies to Medical Error among Turkish Cardiology and Cardiovascular Surgery Nurses. Journal of Patient Safety. Volume 15, Issue 1, 1 March 2019, Pages 1-6. DOI 10.1097/PTS.0000000000000202.

17. Martin-Fumadó C., Morlans M., Torralba F., Arimany-Manso J. Medical errors communication. Ethical and medicolegal issues. Medicina Clinica. Volume 152, Issue 5, 1 March 2019, Pages 195-199. DOI: 10.1016/j.medcli.2018.07.013

18. Scientific and Practical Commentary of the Criminal Code of Ukraine Kyiv, 2018.

19. Nováková M. Frail geriatric patient. Aktuality v Nefrologii. Volume 24, Issue 4, 2018, Pages 130-137 
Topical Issues of Criminal Liability of Medical or Pharmaceutical Workers Under the Criminal Code of Ukraine (Article 140 Of the Criminal Code of Ukraine)

20. Pogosov A.V., Laskov V.B., Bogushevskaya Yu.V. The reasons for an unjustified visit by patients with somatoform disorders to general practitioners. Nevrologiya, Neiropsikhiatriya, Psikhosomatika.Volume 10, Issue 4, 2018, Pages 40-45. DOI: 10.14412/2074-2711-2018-4-40-45.

21. Sampene K.C., Littleton E.B., Kanter S.L., Sutkin G. Preventing Error in the Operating Room: Five Teaching Strategies for High Stakes Learning. Journal of Surgical Research. Volume 236, April 2019, Pages 12-21. DOI: 10.1016/j.jss.2018.10.050.

22. Portela Romero M., Bugarín González R., Rodríguez Calvo M.S Human error, patient safety and medical training. Educacion Medica. Volume 20, March 2019, Pages 169-174. DOI: 10.1016/j.edumed.2017.07.027.

\section{AUTHORS PROFILE}

Sofiia Lykhova, National Aviation University (Kyiv, Ukraine), https://orcid.org/0000-0001-7143-5325,k_kpipp@ukr.net,

+38(067)-446-94-85

Iryna Ustynova, National Aviation University (Kyiv, Ukraine),

Olga Husar, National Aviation University (Kyiv, Ukraine),

Iryna Tolkachova, National Aviation University (Kyiv, Ukraine) 